\title{
The Internet And Gray Marketing
}

\author{
Soumava Bandyopadhyay, Lamar University, USA
}

\begin{abstract}
The purpose of this conceptual paper is to investigate the nature, extent, and outcomes of gray marketing on the Internet. We examined the current state of Internet-based gray marketing in several product categories and found the phenomenon to be on the rise. Next, we developed a series of propositions to address evolving trends in online gray marketing, regarding actions of intermediaries and manufacturers, response by consumers, and outcomes on marketing strategy.
\end{abstract}

Keywords: Gray Marketing, Internet Marketing, Marketing Channels

\section{INTRODUCTION}

ray marketing occurs when genuine and legitimately manufactured trademarked products intended for a particular country market are diverted to a different country market through unauthorized distribution channels. The practice is also known as parallel importation (Duhan and Sheffet, 1988). Gray market activity is estimated to account for over $\$ 40$ billion in revenue each year (Kotler and Keller, 2009, p.617). The predominant reason for gray markets to exist is manufacturer-maintained price differentials across international markets (Berman, 2004). For competitive reasons, manufacturers often price the same product differently in different markets. Gray marketers purchase products at cheaper prices from distributors in other countries (mainly the Far East and Europe), where manufacturers maintain lower prices than in the U.S., and offer substantial discounts below list price when reselling these products at retail in the U.S. market. Currency exchange rate fluctuations and disparate taxation across international markets can also cause price differentials and therefore, create similar opportunities for gray marketers. A wide range of well-known brand name products have been found to be distributed via the gray market, from pharmaceutical drugs and cigarettes to consumer electronics, and even automobiles.

Most manufacturers and trademark owners in the U.S. are not legally protected from gray marketing (Mathur, 1995). Section 526 of the Tariff Act of 1930 forbids importation of goods manufactured in foreign countries without the permission of the trademark owner. The act, however, includes several exceptions, and the U.S. Customs Service, which is responsible for implementing the act, has not been consistent in its enforcement (Keegan and Green, 2008, p.384). The court system has also ruled in favor of gray marketers on many occasions (Duhan and Sheffet, 1988).

For gray marketing to be successful, easy access to unauthorized distribution channels is essential. The gray market intermediary must have access to a product source abroad, and the consumer must have easy access to a gray market retailer selling the product at a cheaper than usual price. The Internet provides a great opportunity to gray marketers to find products in foreign markets for prices less than those in the home market, as well as to reach out to a potentially large number of customers who would be willing to buy these products at substantially lower prices than they can find at manufacturer-authorized retailers (Berman, 2004). The Internet is a global medium that makes physical distance and locational barriers irrelevant, and electronic commerce transcends time zones and can take place round the clock (Strauss and Frost, 2009). Gray marketing, therefore, has seen a tremendous growth using the Internet as a distribution channel. Efforts by manufacturers to stifle gray markets on the Internet have mostly been unsuccessful, because communication over the Internet is difficult to monitor and control (Collard and Roquilly, 2002).

The purpose of this paper is to explore the nature, extent, and outcomes of gray marketing when the Internet is used as the channel of distribution. First, we describe the current gray marketing practices with examples. 
Next, we develop a series of propositions to address evolving trends concerning Internet-based gray marketing. These include the actions of intermediaries and manufacturers, consumer response, and the impact on the marketing mix.

It is to be noted that our research focuses on Internet-based gray marketing activities in the United States, mainly because the United States is the single largest e-commerce market in the world (Strauss and Frost, 2009). The phenomenon of gray marketing is not restricted to the United States, however. For example, Japanese intermediaries have often found it cheaper to go to foreign countries to buy export versions of Japanese-made products and resell them in the domestic gray market, because of the high value of the yen and the Japanese government's subsidization of cheaper exports through high taxes (Czinkota and Ronkainen, 2006).

\section{GRAY MARKETING ON THE INTERNET}

To preserve control over pricing, services, and other marketing variables, manufacturers often build 'closed distribution' structures, whereby distributors are carefully chosen on specific qualitative criteria, and exclusive territories and other concessions are granted to authorized distributors within the network (Collard and Roquilly, 2002). With the growth of Internet retailing, which transcends physical location and distance between seller and buyer, as well as enables low-cost operation, the territories of these authorized distributors are no longer guaranteed. An unauthorized Internet retailer can easily undercut the prices of authorized resellers in their sales territories (Viscounty, Risher, and Smyser, 2001). The Internet-based gray marketer could be based in the U.S. and buying products in foreign countries for reselling in the U.S.; or he could be based in a foreign country and buying products at low local prices and then reaching out to U.S. consumers via its Web site. In the latter case, the retailer may even be authorized by the manufacturer to sell in its local market, but may take advantage of the Internet to expand into unauthorized foreign territory. The legal contract with the manufacturer forbids such diversion, but the manufacturer would find it difficult to monitor the unauthorized selling, particularly when the retailer can easily set up a dummy firm and Website to conduct Internet sales.

We will examine the current Internet-based gray marketing trends in three specific product categoriespharmaceutical drugs, tobacco, and consumer electronics. A keyword search for gray marketing on several major Internet search engines indicated that a high percentage of gray marketing on the Internet occurs in these product categories.

\section{Pharmaceutical Drugs}

The gray market for imported drugs was worth an estimated $\$ 5$ billion a year, or $4.8 \%$ of all drugs sold in the United States, as far back as in 2003 (Haddad, 2003). A more recent study indicates that 11 percent of Americans have reported obtaining less-expensive prescription drugs from other countries, mostly over the Internet (Kesselheim and Choudhry, 2008). The practice is not strictly legal, but it still happens mainly because public opinion seems to favor it in the light of high prescription drug prices in the United States. There are numerous online pharmacies (Canadadrugs.com, medsforless.com, northwestpharmacy.com, for example, to name only a few) that sell gray market prescription drugs to U.S. consumers. Many of them post price comparisons with prevailing prices in the U.S., and claim savings of 10 to 80 percent, or even more.

The pharmaceutical companies are lobbying to have a complete ban on the sales of gray market drugs enacted and enforced in the U.S., but they do not have much sympathy in the face of opposition from many consumer activist groups, such as the American Association of Retired Persons (McGuire, 2006). The American government has not made a very strong effort to stop the parallel importation (also called reimportation) of prescription drugs, particularly those from Canada where the drugs are generally perceived to be made under similar safety standards as in the United States. The current Obama administration supports drug reimportation (Bush, 2009). Earlier, in 2007, the U.S. Congress passed the Pharmaceutical Market Access and Drug Safety Act, which permitted importation of drugs from registered importers from certain countries, such as Canada (Kesselheim and Choudhry, 2008). The lawmakers have been trying to show their constituencies, particularly the senior citizens, that they are sensitive to rising healthcare costs. Legislative action in the United States has so far mainly targeted the so called "rogue" online pharmacies-Websites that sell unapproved drugs, drugs that contain dangerous ingredients, 
or drugs that are dispensed without a proper prescription (Pack, 2009). The Ryan Haight Online Pharmacy Consumer Protection Act was passed in 2008 to shut such rogue pharmacies down (Frederick, 2008).

\section{Tobacco}

The high price of cigarettes in the U.S. due to high taxes prompted a boom in the sales of gray market cigarettes on the Internet in the 1990s (Singer, 1999). Gray market cigarettes fall into two categories: 1) cigarettes that are manufactured in the U.S. and are intended by the manufacturer "for export only" which are re-imported and sold in the U.S.; and 2) cigarettes carrying U.S. brand names that are being sold in the U.S., despite the fact that they were manufactured in other countries for sale in markets other than the U.S. The Federal government passed the Imported Cigarette Compliance Act in 2000, whereby the importation of cigarettes into the U.S. bearing registered U.S. trademarks without the authorization of the trademark owner was outlawed. However, the problems in monitoring Internet-based retailers, and the fact that many of these online cigarette vendors operate from foreign countries, make it difficult to stop the online sales of gray market cigarettes. Even though any online cigarette sales without paying duties and taxes are illegal, these foreign-based online merchants continue to boldly advertise taxfree cigarettes on their Web sites. An Internet search using the popular search engine Google brought up a large number of such Web sites (for example, cigoutlet.net, shop4smokers.com, and cigarettesforless.com). As an illustrative example of the potential cost-savings for consumers, these Web sites advertise a carton of Marlboro cigarettes (made in countries like Philippines and Switzerland) for about $\$ 17$, nearly half the price prevailing in U.S. supermarkets. These companies ship their orders to U.S. buyers in unmarked packages that frequently pass for books or other non-cigarette items at U.S. customs. Recently, Philip Morris was successful in pursuing legal action in closing down one such online retailer, the Swiss-based Yesmoke.com (Dunai, 2004). Philip Morris has also initiated lawsuits against several others, but the continued operation of many other online gray market cigarette vendors indicates a rough road ahead for the company.

\section{Consumer Electronics}

Consumer electronics constitute probably the biggest online gray market. The main reasons are: 1) substantial differences in prices of consumer electronics products between the United States and other countries, particularly the Far East, that appeal to the profit motives of gray marketers; 2) the high growth of online retail sales of electronics; 3) price sensitivity of consumers buying electronics products; and 4) virtually no legal protection against gray marketing of consumer electronics (unlike pharmaceuticals or tobacco).

A search for almost any popular consumer electronics item (such as digital cameras, camcorders, mobile phones, audio components, etc.) using any shopping search engine (such as pricegrabber.com, mysimon.com, shopzilla.com, etc.) on the Internet reveals dealers offering products at hundreds of dollars below retail prices. Many of these products are gray goods imported without the manufacturer's authorization from foreign countries, and 10 to 40 percent discounts off U.S. retail prices are common. Some major online retailers, such as Broadway Photo (www.broadwayphoto.com) and One Stop Camera and Electronics (www.1stopcamera.com) mark gray market products listed on their Web site as "international" models.

\section{RESEARCH PROPOSITIONS}

Based on our understanding of the different forces that act on gray marketing activities on the Internet (both in support of and against), we will develop some propositions regarding current and future trends. We will address the actions of intermediaries and manufacturers who are affected by online gray marketing, the response from consumers, and the impact on marketing strategy.

\section{Intermediaries Involved in Online Gray Marketing}

The Internet offers very low entry barriers to marketers (Strauss and Frost, 2009). It costs little to open a Web site and offer products for sale online. While it can still cost substantially to design and maintain a large-scale, commercial Web site like Amazon.com, a small business or even an individual can start selling online with a moderate inventory for just a few hundred dollars. Submission of a Web site to major search engines following their 
recommended criteria, including clever use of meta-tags, can enable a smaller Web site to be called up by the search engines in response to consumer queries quite easily, thus potentially leveling the playing field between big and small businesses. There may not even be a need to have one's own Web site-it may be possible to sell through other, more established Web sites such as EBay or Amazon.com (as an Amazon z-shop).

Encouraging free-riders is mentioned as one of the negative outcomes of gray marketing (Chen, 2002). The unauthorized retailer selling a gray market product is free-riding on the authorized retailers who spend money on promotional activities and pre- and after-sales services. From an economic perspective, however, free-riding through gray marketing has been identified as a viable strategy for resource-constrained small and entrepreneurial businesses to penetrate established markets (Lee, Lim, and Tan, 1999; Lim, Lee and Tan, 2001). Such businesses will also find online selling to be attractive because of the low entry barriers. Based on this observation, we have our first proposition:

Proposition 1: Intermediaries who engage in gray marketing on the Internet will be mostly small and entrepreneurial businesses.

\section{Manufacturer Actions and Consumer Response}

As discussed earlier, manufacturers have few realistic legal options to combat online gray marketing. In the past, manufacturers have used a punitive strategy to combat gray marketing, whereby they have often terminated the distributor rights of intermediaries who were known to divert products purchased from manufacturers to unauthorized resellers (Cespedes, Corey, and Rangan, 1988). Antia et al. (2006) found that severity, certainty, and speed of enforcement in detecting and punishing diverter intermediaries could be effective in deterring gray market activity. However, the borderless distribution system created by the Internet makes it difficult for manufacturers to track down diverters. The demand for new control systems that could be implemented online has led to the development of some new technologies (Festa, 2005). Net Enforcers (www.netenforcers.com) and Opsec Security (www.opsecsecurity.com) are two firms that have developed software-based solutions to help monitor resellers and trans-shippers who sell products on the Internet without manufacturer authorization by tracking and tracing key information on products (e.g., serial numbers, radio frequency identification tags, bar codes, trademark and logos) that are advertised for sale online. Net Enforcers currently boasts 105 clients that include JVC, Pioneer, and Kenwood. Thus, we have the following proposition:

Proposition 2: Manufacturers will increase spending on new software-based technologies to combat online gray marketing with the increase in such gray marketing activities.

Traditionally, another popular approach by manufacturers to combat gray marketing has been to discourage consumers from buying gray market products by denying warranty service on products purchased from unauthorized retailers (Berman, 2004). Gray marketers have fought back by offering their own store warranties on such products. The Internet allows consumers to have easy access to these alternative warranties when the information is posted on the gray marketer's Web site. Also, lower prices and reputable brand names on gray products often mean that customers do net get too concerned about the manufacturer's warranty.

Manufacturers also try to produce physically different versions of same products for different country markets (Berman, 2004), such as different model names and numbers and other apparent physical differences, in an attempt to dissuade consumers from buying gray goods by making it difficult to compare gray market products and their prices with those offered by authorized retailers. They also use the Internet to offer gray market product advisories to consumers. For example, Olympus Corporation has an advisory posted on their Web site (www.olympus.co.jp/en/support/imsg/digicamera/qa/), where they warn U.S. consumers of the disadvantages of buying gray market digital cameras, such as foreign language instruction manuals and the lack of warranty service. However, the same Internet medium that provides manufacturers the opportunity to conveniently educate a large number of consumers about the disadvantages of buying gray goods, also provides consumers the opportunity to make informed buying decisions that could help them benefit from the low prices of such goods. There are plenty of information sources on the Internet (search engines, product review sites, discussion groups, etc.) for consumers to objectively compare features of products offered in different country markets and see through manufacturers' efforts 
to create a perception of differentiated products. Comparison of products offered by a manufacturer in different countries can often be made by following the various country links on the manufacturer's own Web site. Many manufacturers' Web sites also contain product instruction manuals in various languages that can be easily downloaded by consumers who may have purchased gray market products with manuals written in languages other than English.

The preceding discussion leads to our next proposition:

Proposition 3: Traditionally used manufacturer efforts, such as denying warranty service and maintaining product differentiation across markets, to discourage consumers to buy gray market products will be ineffective when gray products are distributed over the Internet.

\section{Impact on Marketing Strategy}

Our investigation of gray marketing in various product categories showed that there are legal means to effectively combat physical gray channels in certain products, such as prescription drugs and tobacco. We have also seen in an earlier section of this paper that online gray marketing is quite rampant in these product categories. This happens because of the difficulties in enforcing existing law to shut down online channels. Hence, we propose:

Proposition 4: Online gray marketing channels will develop in product categories for which there are effective legal means to combat physical gray marketing channels.

The ease with which consumers can compare prices charged by different vendors on the Internet creates a strong downward pressure on Internet prices (Strauss and Frost, 2009). When price becomes one of the most important considerations in a buying decision, gray marketers get a special impetus. To discourage online gray marketing, manufacturers may be forced to reduce the prices of products that are available for sale on the Internet. Therefore, our next proposition is:

Proposition 5: Increasing online gray marketing will result in a reduction of prices by manufacturers.

The price reduction by manufacturers will squeeze reseller margins, and will likely result in the reduction of some services offered by authorized distributors. While such reduction of services may be inevitable, the manufacturers will have to be careful about not causing erosion in brand equity as a result. The higher volume sales sought by manufacturers at lower prices may also mean less selectivity in choosing intermediaries and fewer exclusive distribution contracts. This likely chain reaction leads to the next two propositions:

Proposition 6: Price reduction by manufacturers in response to increasing online gray marketing activities will result in the reduction of services offered by authorized distributors.

Proposition 7: Increasing online gray marketing will result in manufacturers being less selective in appointing authorized distributors.

When products are sold over the Internet, customers can easily find out how much products sell for in different countries. The price transparency is likely to encourage many consumers to buy gray market products sourced from foreign markets at lower prices and reject higher prices charged by authorized resellers in their local market. This could make manufacturers reduce price differentiation between countries and harmonize prices across markets (Masie, 1998). Hence, we have our last proposition:

Proposition 8: Increasing online gray marketing activities will result in reduced price differentials maintained by manufacturers between countries.

\section{CONCLUSION}

In this paper, we explored the nature, extent, and outcomes of gray marketing activities on the Internet. 
Following an examination of Internet-based gray marketing in several product categories, we developed a series of theoretical propositions to address evolving trends in online gray marketing, regarding actions of intermediaries and manufacturers, response by consumers, and outcomes on marketing strategy. We found that online gray marketing is on the rise, and consumers are generally reacting favorably to it. We proposed that online gray marketing would be an attractive market entry strategy particularly for small businesses. Traditional strategies pursued by manufacturers to combat gray marketing, such as denial of warranty services on gray goods and product differentiation across country markets are not likely to discourage consumers from buying gray market products online. Legal recourses, even if available, are difficult to implement. Manufacturers may be better off in investing in new software-based technologies to fight online gray marketing through tracking of unauthorized product diversion in the online channel. Finally, our interpretation of current trends led us to propose that increasing gray marketing on the Internet would result in manufacturers reducing prices in high-priced markets (resulting in fewer services offered by resellers), being less selective in the appointment of authorized distributors, and even reducing price differentials between countries. The next logical research step would be to test these propositions by means of an empirical study.

Since our study indicates that gray marketing on the Internet is likely to be an irreversible trend, manufacturers might also consider the strategy of accepting the practice, as long as it does not get out of hand. Some potential benefits of gray marketing have been identified. These include the expansion of the total market to more price elastic segments, thus increasing sales and market share (Duhan and Sheffet, 1988). Pragmatic manufacturers might want to emphasize these possible benefits of gray marketing, rather than the disadvantages.

\section{AUTHOR INFORMATION}

Soumava Bandyopadhyay is a professor of marketing at Lamar University, U.S.A. He received his Ph.D. from The University of Alabama. His areas of research interest include internet marketing, global marketing, and channels of distribution.

\section{REFERENCES}

1. Antia, K.D., Bergen, M.E., Dutta, S., \& Fisher, R.J. (2006). How Does Enforcement Deter Gray Market Incidence? Journal of Marketing, 70 (January), 92-106.

2. Berman, B. (2004). Strategies to Combat the Sale of Gray Market Goods. Business Horizons, 47 (4), 51-60.

3. Bush, L. (2009). How Change Plays Out. Biopharm International, 22 (2), 10.

4. $\quad$ Cespedes, F.V., Corey, E.R. \& Rangan, V.K. (1988). Gray Markets: Causes and Cures. Harvard Business Review, 66 (4), 75-82.

5. Chen, H.L. (2002). Gray Marketing and Unfair Competition. Atlantic Economic Journal, 30 (2), 196-204.

6. Collard, C. \& Roquilly, C. Closed Distribution Networks and E-Commerce: Antitrust Issues. International Review of Law, Computers \& Technology, 16 (1), 81-92.

7. Czinkota, M.R. \& Ronkainen, I.A. (2006). International Marketing, $8^{\text {th }}$ Edition. Mason, OH: Thomson South-Western.

8. Duhan, D.F. \& Sheffet, M.J. (1988). Gray Markets and the Legal Status of Parallel Importation. Journal of Marketing, 52 (July), 75-83.

9. Dunai, M. (2004). Duty-Free Site's Cigarette Sales Draw Scrutiny. Wall Street Journal, August 5, B1.

10. Festa, P. (2005). Net Tightens Gray Market Retail Vise. News.com, http://ecoustics-cnet.com.com, ecoustics-cnet.com.com/Net+tightens+gray-market+retail+vise/2100-1030 3-5628742.html.

11. Frederick, J. (2008). Congress Clamping Down on Illegal Online Rx. Drug Store News, 30 (12), 24.

12. Haddad, C. (2003). Can Rogue Pharmacies Be Roped In? Business Week Online, October 16, http://www.businessweek.com/print/bwdaily/dnflash/oct2003/nf20031016_2164_db016.htm.

13. Keegan, W.J. \& Green, M.C. (2008). Global Marketing, $5^{\text {th }}$ Edition. Upper Saddle River, NJ: Prentice Hall.

14. Kesselheim, A.S. \& Choudhry, N.K. (2008). The International Pharmaceutical Market as a Source of LowCost Prescription Drugs for U.S. Patients. Annals of Internal Medicine, 148 (8), 614-619.

15. Kotler, P. \& Keller, K.L. (2009). Marketing Management, $13^{\text {th }}$ Edition. Upper Saddle River, NJ: Prentice Hall. 
16. Lee, K.S., Lim, G.H. \& Tan, S.J. (1999). Dealing with Resource Disadvantage: Generic Strategies for SMEs. Small Business Economics, 12 (4), 299-311.

17. Lim, G.H., Lee, K.S. \& Tan, S.J. (2001). Gray Marketing as an Alternative Market Penetration Strategy for Entrepreneurs: Conceptual Model and Case Evidence. Journal of Business Venturing, 16 (4), 405.

18. Masie, E. (1998). Global Pricing in an Internet World. Computer Reseller News, May 11, 55-58.

19. Mathur, L.K. (1995). The Impact of International Gray Marketing on Consumers and Firms. Journal of Euromarketing, 4 (2), 39-59.

20. McGuire, S. (2006). Drug Reimportation is Back at Forefront. Medical Marketing and Media, 41 (11), 10.

21. Pack, T. (2009). Shopping at Online Drugstores. Information Today, 26 (6), 44-45.

22. Singer, S. (1999). Thriving Gray Market Cuts Florida's Piece of Tobacco Settlement. Sun Sentinnel, March 4.

23. Strauss, J. \& Frost, R. (2009). E-Marketing, $5^{\text {th }}$ Edition. Upper Saddle River, NJ: Prentice Hall.

24. Viscounty, P.J., Risher, J.C. \& Smyser, C.G. (2001). Cyber Gray Market is Manufacturers' Headache. National Law Journal, 23 (52), C3. 
NOTES 